\title{
LASERTERAPIA ULCERELOR DE GAMBĂ DIN DIABETUL ZAHARAT
}

Considerații preliminare asupra laserterapiei la 4 ani de utilizare într-un praxis de medicina familiei

\section{dr. Bumbuluț Călin, medic primar medicina familiei, instructor formator în medicina}

familiei, CMI, Satu Mare

Efectele biologice ale laserului de putere mică sunt: analgezic, antiinflamator, antiedematos, miorelaxant şi antibacterian, antiviral. Rezultatele studiilor preclinice şi clinice de până acum au dus la următoarele concluzii:

1. Laserterapia de putere joasă acționează asupra sintezei de prostaglandine intensificând transformarea PGG2 şi PGH2 în PG12 [1]. Laserul cu diodă semiconductoare Ga-As 904 nm se pare că este alegerea cea mai bună în terapia de ameliorare a durerii.

2. Există o creştere semnificativ statistică a numărului vaselor dermale după laserterapie de putere joasă [2].

3. Iradierea cu o sursă de $120 \mathrm{~mW}, \mathrm{Ga}-A s$ cu $\lambda 904 \mathrm{~nm}$ pulsatil cu energii variind între 3 şi $5 \mathrm{~J} /$ cmp stimulează proliferarea fibroblaştilor de 3 până la 6 ori comparativ cu lotul de control, fără a influența sinteza de procolagen [3]. Acest efect a fost restrâns la o plajă îngustă de energie întrucât expunerea la peste $5 \mathrm{~J} / \mathrm{cmp}$ nu a avut efect asupra creșterii celulare.

4. Inducerea vindecării complete în ulcerele refractare cu laserterapie de intensitate joasă depinde de cauza ulcerului şi de mărimea lui [4].

Rezultatele de la introducerea LT în practica personală au fost încurajatoare în tratamentului ulcerului trofic de gambă posttrombotic, concluziile fiind următoarele [5]:

1. durerea locală a fost primul simptom remis relativ rapid - în medie în prima săptămână de tratament

2. edemul gambei, cel perilezional şi secreția s-au redus de asemenea în primele 2 săptămâni de tratament

3. crustizarea s-a produs în medie la 4 săptămâni de la inițierea LT, leziunea nemaifiind ulterior pansată

4. nu s-a utilizat nici-o altă terapie (medicamentoasă sau fizicală) pe parcursul LT, în afara regimului de evitare a efortului fizic şi a drenajului postural nocturn.

5. urmărirea cazurilor pe o perioada de până la 4 ani nu a arătat recidive decât în 2 cazuri şi pe alte zone decât cele tratate inițial, cu închidere de fiecare dată a noilor leziuni sub LT.

Ulcerul de picior prin neuropatie diabetică reprezintă o încercare probabil mai redutabilă datorită complicaţiilor macro şi microvasculare concomitente, tratamentele prin terapie laser de intensitate joasă fiind puține în literatură, precum şi studiile clinice. Ulcerul cronic de gambă este comun în evoluția în timp a diabetului şi poate semnala complicații severe, fiind deseori rezistent la terapie.

Î̉ntr-un studiu [6] s-a urmărit evaluarea eficacității laserterapiei de intensitate joasă pentru inducerea vindecării ulcerului de gambă prin neuropatie diabetică la un bărbat cu diabet zaharat tip I, neuropatie senzorială, macro şi microangiopatie, care suferă şi de un ulcer la piciorul stâng şi osteomielită de 6 săptămâni. După un total de 16 şedințe de laserterapie la $670 \mathrm{~nm}$ timp de 4 săptămâni ulcerul a fost vindecat. Pe o perioadă de 9 luni, urmărirea nu a arătat recurența ulcerului deşi statusul metabolic al pacientului a rămas instabil. Deşi laserterapia nu a fost utilizată ca monoterapie, observația sugerează că ea poate reprezenta o alternativă neinvazivă de inducere a vindecării ulcerului neuropatic la pacienții diabetici. Studiul subliniază că sunt necesare studii randomizate controlate ulterioare.

Pentru a evalua efectele terapiei adjuvante cu oxigen hiperbar şi laserterapie de energie joasă în vindecarea ulcerului cronic de gambă diabetic rezistent la tratamentul convențional, au fost cuprinşi într-un studiul 
prospectiv deschis [7] 100 de pacienți cu ulcer cronic de gambă diabetic, refractar la tratamentul clasic de 4,5 $\pm 1,2$ luni. În timp ce tratamentul convențional a fost continuat în unele cazuri, terapia cu oxigen hiperbar a fost aplicată prin pomparea de oxigen 100\% într-o cameră de polietilenă hiperbară de unică folosinţă, 150 minute de 2-3 ori pe săptămână, până la 1,04 atm. În paralel a fost utilizat un laser Heliu-Neon, cu o energie de $4 \mathrm{~J} / \mathrm{cmp}$ timp de 20 minute. Unii pacienți au continuat terapia hiperbară la domiciliu sau au efectuat în întregime tratamentul la domiciliu. Au fost monitorizați la fiecare 2 săptămâni, evidențiindu-se un procent de $81 \%$ vindecări după $25 \pm 13$ şedințe pe o perioadă de 3,2 $\pm 1,7$ luni. La urmărirea ulterioară (mediana 18 luni) doar 3 din 81 pacienți (4\%) au avut recidive care au răspuns la reaplicarea tratamentului menționat.

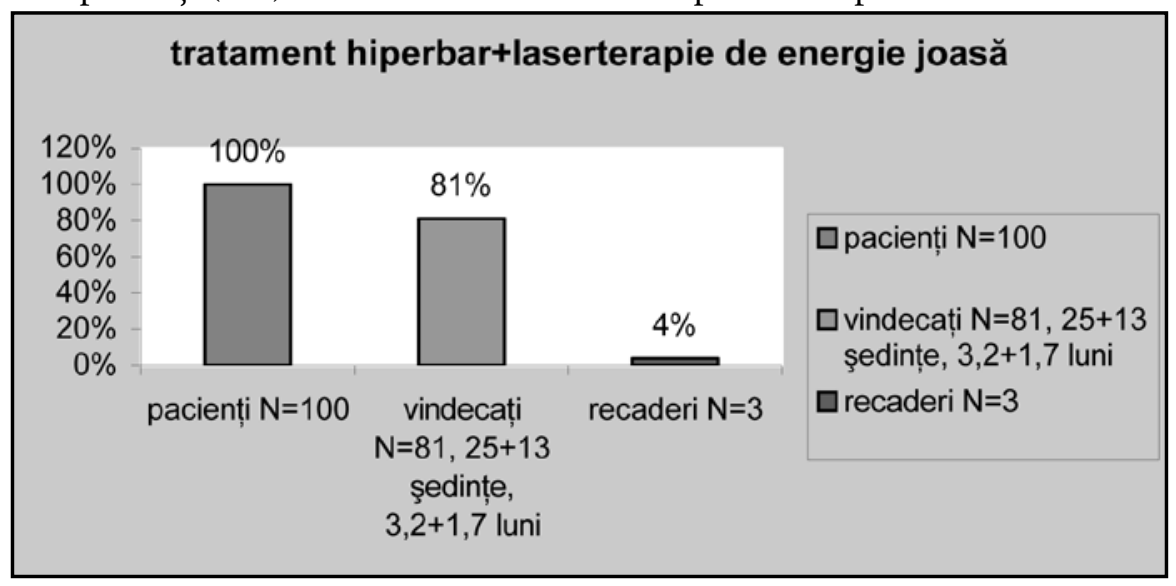

Cei nonresponsivi au avut un indice gleznă-braț semnificativ mai redus decât cei cu ulcer vindecat ( 0,55 vs. $0,78, P<0,01)$, necesitând în ultimă instanță amputație. Complianța pacienților a fost totală şi nu au apărut efecte adverse. În concluzie, deşi studiul a fost deschis şi necontrolat, un procent de $81 \%$ vindecări la pacienți care anterior nu au răspuns la tratamentul clasic, a constituit un rezultat preliminar care intrigă. Astfel, terapia combinată hiperbară-laserterpie ar putea constitui un tratament sigur, simplu şi ieftin pentru pacienții cu ulcer cronic diabetic de gambă. Aceste date necesită evaluare prin studii mai largi, randomizate, controlate.

Încercarea de a evalua eficacitatea laserterapiei printr-un studiu la nivelul unui cabinet de medicina familiei este imposibilă datorită particularităților asistenței primare, cazurilor neselectate, prevalenței şi incidenței complicațiilor diabetului şi nu în ultimul rând celor financiare. Din totalul pacienturii (N=2572), pacienții cu diabet $(\mathrm{N}=77)$ reprezintă 2,99\%, din care 98,7\% (76) sunt cu DZ tip 2. Pacienții care au prezentat ulcere trofice au fost în număr de 2 (2,59\%), din care unul a avut şi complicaţii de tip tromboflebitic. Pentru o încercare de comparație, la nivel naţional din datele colectate la nivelul Comisiei de Diabet, Nutriție, Boli Metabolice a Ministerului Sănătății la 31.12.2003, din 404.150 (1,80\% din populație) bolnavi de diabet: - 33.953 aveau DZ1, iar 370.197 (91,60\%) - DZ tip 2.

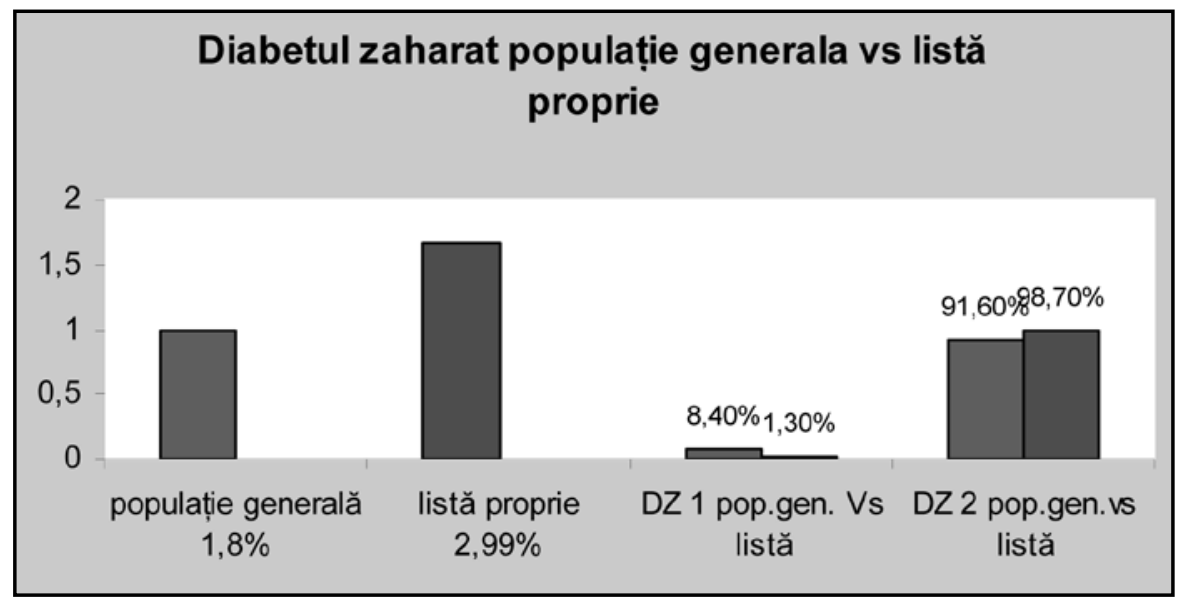


Din datele epidemiologice mondiale, 25\% dintre bolnavii cu DZ internați sunt spitalizați pentru complicații la nivelul piciorului, iar 50 până la 70\% dintre amputațiile netraumatice sunt la pacienții cu DZ. Neuropatia diabetică este a doua cauză, pe plan mondial, de durere neuropată, după lumbago.

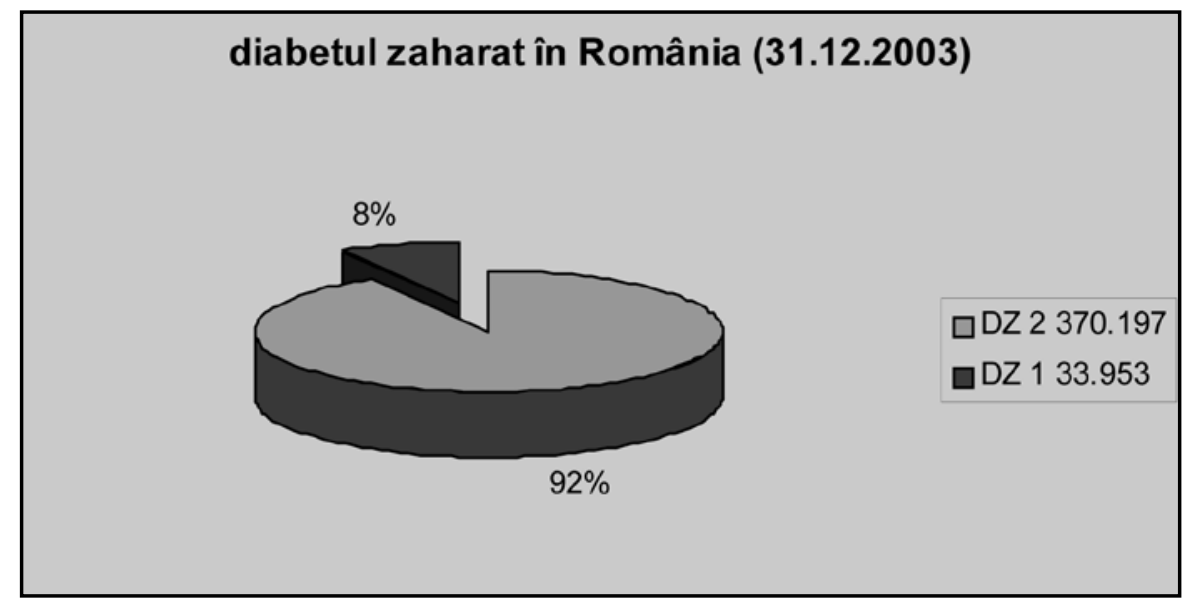

Pacienții au fost supuşi laserterapiei cu un aparat laser portabil clasa III B, cu parametri de lucru variabili (frecvență, densitate, putere de lucru, suprafață iradiată, timp de expune), cu o sondă digitală cu diodă semiconductoare Ga-As, infraroşu $\lambda 830 \mathrm{~nm}$, cu putere de ieşire $50 \mathrm{~mW}$ pe o suprafață de 1 cmp, cu posibilitate de lucru în mod continuu sau pulsatil, cu radiație convergentă, cu ghid optic în spectru vizibil. Programele folosite au fost presetate pentru ulcer trofic:

- putere $50 \mathrm{~mW}$, aria de expunere $1 \mathrm{cmp}$, densitate de putere - energia - $3 \mathrm{~J} / \mathrm{cmp}$, mod continuu, timp de expunere 1 minut.

- putere $50 \mathrm{~mW}$, aria de expunere $1 \mathrm{cmp}$, densitate de putere $3 \mathrm{~J} / \mathrm{cmp}$, mod pulsatil cu o frecvență de $5 \mathrm{~Hz}$, timp de expunere 1 minut 15 secunde.

Cele două programe au fost folosite în succesiune pe ariile afectate, perilezional, 5 zile pe săptămână.

Monitorizarea schimbărilor pe parcursul tratamentului s-a făcut prin fotografierea la fiecare şedință LT a leziunilor cu o cameră foto digitală.

Caz 1: bărbat de 58 de ani cunoscut cu DZ tip II, boală varicoasă a membrelor inferioare, picior diabetic, stare post amputație deget $\mathrm{V}$ picior drept, arteriopatie cronică obliterantă a membrelor inferioare, HTA stadiul II formă uşoară, dislipidemie mixtă, steatoză hepatică, obezitate; este începută laserterapia conform protocolului pe aria de amputație care nu avea tendință de închidere la 2 luni de la operație (foto 1).

Complianța pacientului a fost redusă, ritmul prezentărilor la terapie fiind uneori de 2/ săptămână.

Terapia medicamentoasă a întâmpinat de asemenea dificultăți în ceea ce priveşte complianța.

La 44 zile de la inițierea LT, aria ulcerativă s-a restrâns progresiv (foto 2), iar la 70 de zile (30 şedințe) s-a micşorat aproape de închidere (foto 3). Ulterior pacientul nu s-a mai prezentat 2 luni la cabinet, motivând ulterior că plaga se închisese. La o urmărire de 2 ani, leziunea este vindecată, neexistând recidive.

Caz 2: bărbat de 57 ani, în evidență cu scăderea toleranței la glucoză, HTA stadiul II formă uşoară, hepatita cronică activă, CIC cu AP de efort, sindrom posttrombotic membru inferior stâng, se prezintă pentru o ulcerație la nivelul feței anterolaterale a piciorului stâng apărută în urma unui traumatism minor local (foto 4). Este iniţiată laserterapia, iar la 60 de zile (40 şedințe) ulcerația este vindecată (foto 5). După 2 ani, nu există recidivă.

La 4 ani de la introducerea laserterapiei în practica cabinetului putem formula următoarele concluzii preliminare:

1. Se impune evaluarea prin studii controlate a laserterapiei, care poate fi un instrument alternativ valoros neinvaziv pentru inducerea vindecării în ulcerele de gambă 
2. Utilitatea laserterapiei raportată la cazuistica din asistența primară şi la experiența personală se pare că este maximă în durerile din periartrita scapulohumerală, zona zooster şi herpes simplex, osteofitoză, în ulcerele trofice de gambă posttrombotice şi probabil cele diabetice.

3. Nu putem vorbi de rentabilitate, după 4 ani nefiind amortizată investiția inițială decât în proporție de $80 \%$. Ținând însă cont de durata medie de viață a unei sonde de 10.000 ore, există speranțe privind rentabilizarea pe termen lung.

\section{Bibliografie}

1. Tam G: Low power laser therapy and analgesic action. J Clin Laser Med Surg 1999 Feb;17(1):29-33 (ISSN: 1044-5471)

2. Schindl A; Schindl M; Schindl L; Jurecka W; Honigsmann H; Breier F: Increased dermal angiogenesis after low-intensity laser therapy for a chronic radiation ulcer determined by a video measuring system. J Am Acad Dermatol 1999 Mar;40(3):481-4 (ISSN: 0190-9622)

3. Pereira AN; Eduardo Cde P; Matson E; Marques MM: Effect of low-power laser irradiation on cell growth and procollagen synthesis of cultured fibroblasts. Lasers Surg Med 2002;31(4):263-7 (ISSN: 0196-8092)

4. Schindl M; Kerschan K; Schindl A; Schon H; Heinzl H; Schindl L: Induction of complete wound healing in recalcitrant ulcers by low-intensity laser irradiation depends on ulcer. Division of Special and Environmental Dermatology, Allergy and Infectious Diseases, University of Vienna Medical School, Vienna, Austria

5. Bumbuluț C: Laserterapia ulcerelor de gambă: între realitate şi contestare. Medical Update decembrie 2006, 24 (vol V): 198-203 (ISSN: 1454-1882)

6. Schindl A; Schindl M; Pernerstorfer-Schon H; Kerschan K; Knobler R; Schindl L: Diabetic neuropathic foot ulcer: successful treatment by low-intensity laser therapy. Dermatology 1999;198(3):314-6 (ISSN: 10188665); Division of Special and Environmental Dermatology, Allergy and Infectious Diseases, University of Vienna Medical School, Vienna, Austria. Andreas.Schindl@akh-wien.ac.at.

7. Landau Z; Schattner A: Topical hyperbaric oxygen and low energy laser therapy for chronic diabetic foot ulcers resistant to conventional treatment. Yale J Biol Med 2001 Mar-Apr;74(2):95-100 (ISSN: 0044-0086); The Hebrew University, Hadassah School of Medicine, Jerusalem Israel. 